\title{
IL-27 rs I53 I09 polymorphism increases the risk of colorectal cancer in Chinese Han population
}

This article was published in the following Dove Press journal:

OncoTargets and Therapy

16 June 2015

Number of times this article has been viewed

\section{Shixu Lyu \\ Lechi Ye \\ Ouchen Wang \\ Guanli Huang \\ Fan Yang \\ Yehuan Liu \\ Siyang Dong}

Department of Surgical Oncology, the First Affiliated Hospital of Wenzhou Medical University, Wenzhou, Zhejiang, People's Republic of China
Correspondence: Ouchen Wang Department of Surgical Oncology, the First Affiliated Hospital of Wenzhou Medical University, Wenzhou, Zhejiang 325000 , People's Republic of China Tel +8657755578527

Email fl23beil24@hotmail.com
Abstract: IL-27, a new member of the IL-12 family, has been found to have antitumor effects in colorectal cancer (CRC); therefore, polymorphisms of this protein may modulate $\mathrm{CRC}$ carcinogenesis. So, we studied the association of single nucleotide polymorphisms of the $I L-27$ gene with the risk of CRC occurrence using a case-control using $600 \mathrm{CRC}$ patients and matched healthy controls. The IL-27 rs153109 polymorphism was analyzed with polymerase chain reaction-restriction fragment length polymorphism and DNA sequencing methods. Data indicate that GG, GA, and combined A-variant genotypes (GG + GA) conferred significantly greater risk of $\mathrm{CRC}(P=0.034,0.002$, and 0.001 , respectively), and that $\mathrm{G}$ alleles were associated with higher susceptibility to $\mathrm{CRC}(P=0.001)$. However, no correlation was found between the IL-27 rs 153109 polymorphism and particular clinical features. In conclusion, our data demonstrated a clear association of IL-27 rs153109 polymorphism and the risk of CRC development.

Keywords: IL-27, polymorphism, CRC

\section{Introduction}

Colorectal cancer (CRC) contributes greatly to cancer deaths worldwide. ${ }^{1}$ Although the etiology of CRC is still unknown, researchers accept that CRC pathogenesis is intricate and that dietary, lifestyle, and genetic changes contribute to its incidence. ${ }^{2}$ Growing evidence indicates that genetic polymorphisms are key to $\mathrm{CRC}$ development ${ }^{3-5}$ and that several tumor cell cytokine genes can induce systemic immunity against CRC. Cytokines may activate immunocompetent cells and stimulate a cascade of immune processes to elicit antitumor activity. ${ }^{6}$ IL-27, a novel member of the IL-12 family, was shown to be one such cytokine. ${ }^{7}$

IL-27 is a heterodimeric cytokine comprising a p40-related protein, EBI3, and a newly discovered IL-12 p35-related protein, p28. IL-27 is produced early after activation by antigen presenting cells, and has two distinct immune functions: an initiator of the TH1-type immune response to promote naïve T-cell proliferation and a potent inducer of IFN- $\gamma$ production, participating in host defense against intracellular infection. IL-27 has not only antitumor immune activity via cytotoxic T lymphocytes or natural killer cells, but also has anti-angiogenic properties, a feature first depicted in a murine tumor model of colon carcinoma C26. ${ }^{8-11} \mathrm{C} 26$ cells transduced with single-chain IL-27 cDNA were modified to secrete IL-27 (C26-IL-27) and had minimal tumor growth in vivo. All mice inoculated with $\mathrm{C} 26$ cells survived and had complete tumor remission, indicating that IL-27 can potently induce antitumor activity and protective immunity. ${ }^{10}$

Recently, several studies suggest the role of IL-27 polymorphisms in cancer risk such as esophageal cancer, ${ }^{12}$ ovarian cancer, ${ }^{13}$ nasopharyngeal carcinoma, ${ }^{14}$ 
hepatocellular carcinoma, ${ }^{15}$ and glioma. ${ }^{16}$ Most importantly, associations of the IL-27 rs153109 polymorphism and risk for several diseases such as asthma, COPD, and inflammatory bowel disease have been identified. ${ }^{17-19}$ Little is known about the role of the IL-27 rs 153109 polymorphism in the risk of CRC development. Thus, we investigated this association.

\section{Materials and methods}

\section{Subjects}

Six hundred CRC patients and 600 age- and sex-matched cancer-free controls were recruited in this study. Samples were collected prior to any anticancer treatment between January 2009 and April 2014 in the Department of Surgical Oncology of the First Hospital of Wenzhou Medical University. Diagnosis was established by histopathological examination of the biopsy. CRC patients were staged according to the American Joint Committee on Cancer/International Union against Cancer Tumor-Node-Metastasis (TNM) staging system. Healthy controls were recruited from routine examination from the Department of Health, First Hospital of Wenzhou Medical University. Stratified analyses were performed for combined genotypes ( $\mathrm{GG}+\mathrm{GA}$ versus AA) in CRC patients according to sex, age at admission, differentiation status, tumor growth pattern, lymph node metastasis, and TNM pathological stage. This study was approved by the hospital-based ethics committee and informed consent was obtained from all subjects. Subject data are shown in Table 1.

\section{PBMCs preparation and DNA extraction}

Peripheral blood samples were collected in vacuum tubes with 5\% ethylenediaminetetraacetic acid (EDTA). PBMCs were isolated from blood samples by density gradient centrifugation using lymphocyte separation medium. Genomic DNA was extracted using a DNA Purification Kit (Tiangen Biotech, Beijing, People's Republic of China) according to kit instructions.

\section{IL-27 genotyping}

Genotyping of the IL-27 rs153109 polymorphism was performed by polymerase chain reaction (PCR)-restriction fragment length polymorphism. The forward primer 5-CTGATCCTGACCTCACT CAACGC-3 and the reverse primer 5-CTGACTGG GACTGGGACTCAGC-3 were used for PCR. A $20 \mu \mathrm{L}$ PCR mixture contained 50-150 ng of genomic DNA and $10 \mu \mathrm{L} 2 \times$ PCR mix (Tiangen Biotech). For PCR amplification, an initial denaturation at $94^{\circ} \mathrm{C}$ for 5 minutes was followed by 36 cycles at $94^{\circ} \mathrm{C}$ for 30 seconds, at $64^{\circ} \mathrm{C}$ for 30 seconds, at $72^{\circ} \mathrm{C}$ for 30 seconds, and a final extension at $72^{\circ} \mathrm{C}$ for 10 minutes. BstU I (New England Biolabs Inc., Beverly, MA, USA) was used to detect the A-G transition. PCR products are shown in Figure 1. To confirm genotyping results, PCR-amplified DNA samples were examined by DNA sequence (Figure 2), and the results were 100\% concordant.

\section{Statistical analysis}

Statistical calculations were performed with SPSS statistical software (version 18.0; SPSS Inc., Chicago, IL, USA).

Table I The clinical characteristics of the subjects including CRC and healthy control

\begin{tabular}{|c|c|c|c|}
\hline Variable & $\begin{array}{l}\text { Colorectal cancer } \\
\mathrm{N}=600(\%)\end{array}$ & $\begin{array}{l}\text { Healthy control } \\
\mathrm{N}=600(\%)\end{array}$ & $P$-value \\
\hline \multicolumn{4}{|l|}{ Age } \\
\hline$<50$ years & $186(31.0)$ & $204(34.0)$ & 0.27 \\
\hline$\geq 50$ years & $414(69.0)$ & $396(66.0)$ & \\
\hline \multicolumn{4}{|l|}{ Sex } \\
\hline Male & $350(58.3)$ & $326(54.3)$ & 0.16 \\
\hline Female & $250(4 I .7)$ & $274(45.7)$ & \\
\hline \multicolumn{4}{|c|}{ Alcohol drinking } \\
\hline Yes & $382(63.7)$ & $357(59.5)$ & 0.14 \\
\hline No & $218(36.3)$ & $243(40.5)$ & \\
\hline \multicolumn{4}{|l|}{ Smoking } \\
\hline Yes & $338(56.3)$ & $327(54.5)$ & 0.52 \\
\hline No & $262(43.7)$ & $273(45.5)$ & \\
\hline \multicolumn{4}{|c|}{ Family history of cancer } \\
\hline Yes & $38(6.3)$ & $42(7.0)$ & 0.64 \\
\hline No & $562(93.7)$ & $558(93.0)$ & \\
\hline \multirow{2}{*}{\multicolumn{4}{|c|}{$\begin{array}{l}\text { Family history of colorectal } \\
\text { adenoma or polyp }\end{array}$}} \\
\hline & & & \\
\hline Yes & $183(30.5)$ & $198(33.0)$ & 0.35 \\
\hline No & $417(69.5)$ & $402(67.0)$ & \\
\hline
\end{tabular}

Abbreviation: CRC, colorectal cancer. 


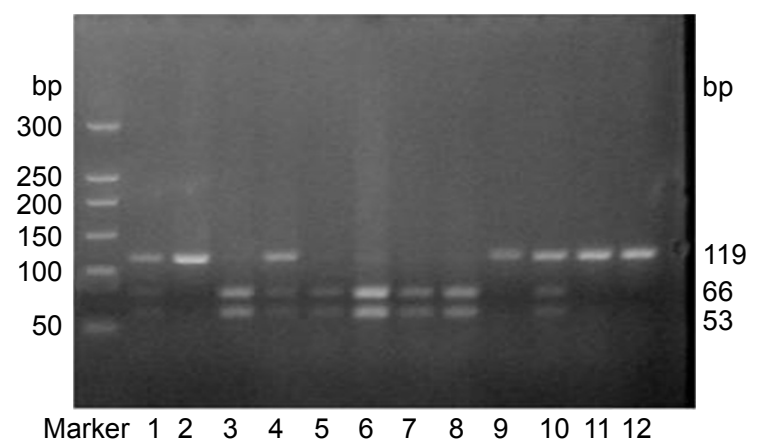

Figure I PCR products of IL-27 of the CRC patients (lane I-6) and control (lane 7-I2).

Genotype frequencies were analyzed with a chi-squared test. Differences were considered significant at $P<0.05$.

\section{Results}

\section{Clinical characteristics of patients}

CRC patients and healthy controls $(\mathrm{N}=600$, each) were recruited for the present study. CRC patients ( $41.7 \%$ women) were diagnosed as TNM stage I plus II (38.0\%) and stage III plus IV $(62.0 \%)$.

\section{IL-27 rs I 53I09 polymorphism results}

The genotype and allele frequency of the IL-27 rs153109 polymorphism was detected by PCR-restriction fragment length polymorphism and the GG, GA, and combined G variant genotypes $(\mathrm{GG}+\mathrm{GA})$ conferred significantly greater risk of CRC ( $P=0.034,0.002$, and 0.001, respectively). Moreover, $\mathrm{G}$ alleles were associated with higher susceptibility to CRC ( $P=0.001)$ (Table 2$)$. Stratified analyses for combined genotypes ( $\mathrm{GG}+\mathrm{GA}$ versus $\mathrm{AA})$ in CRC patients according to sex, age at admission, differentiation status, tumor growth pattern, lymph node metastasis, and TNM pathological stage, were performed to correlate clinical stages with genotypes, and no significant differences were observed (Table 3).

\section{Discussion}

$\mathrm{CRC}$ is one of the most common cancers and its incidence and mortality is increasing in the People's Republic of China annually. ${ }^{20}$ Genetic screening for specific cancer risks is useful but more work is needed to identify susceptibility genes involved in cancer. ${ }^{21}$ Single nucleotide polymorphisms are the most common sources of human genetic variation, and these may contribute to an individual's susceptibility to CRC. ${ }^{3-5}$

IL-27, a newly discovered heterodimeric cytokine of the IL-12 family, displays not only anti-proliferative and anti-angiogenic effects by directly acting on cancer cells,
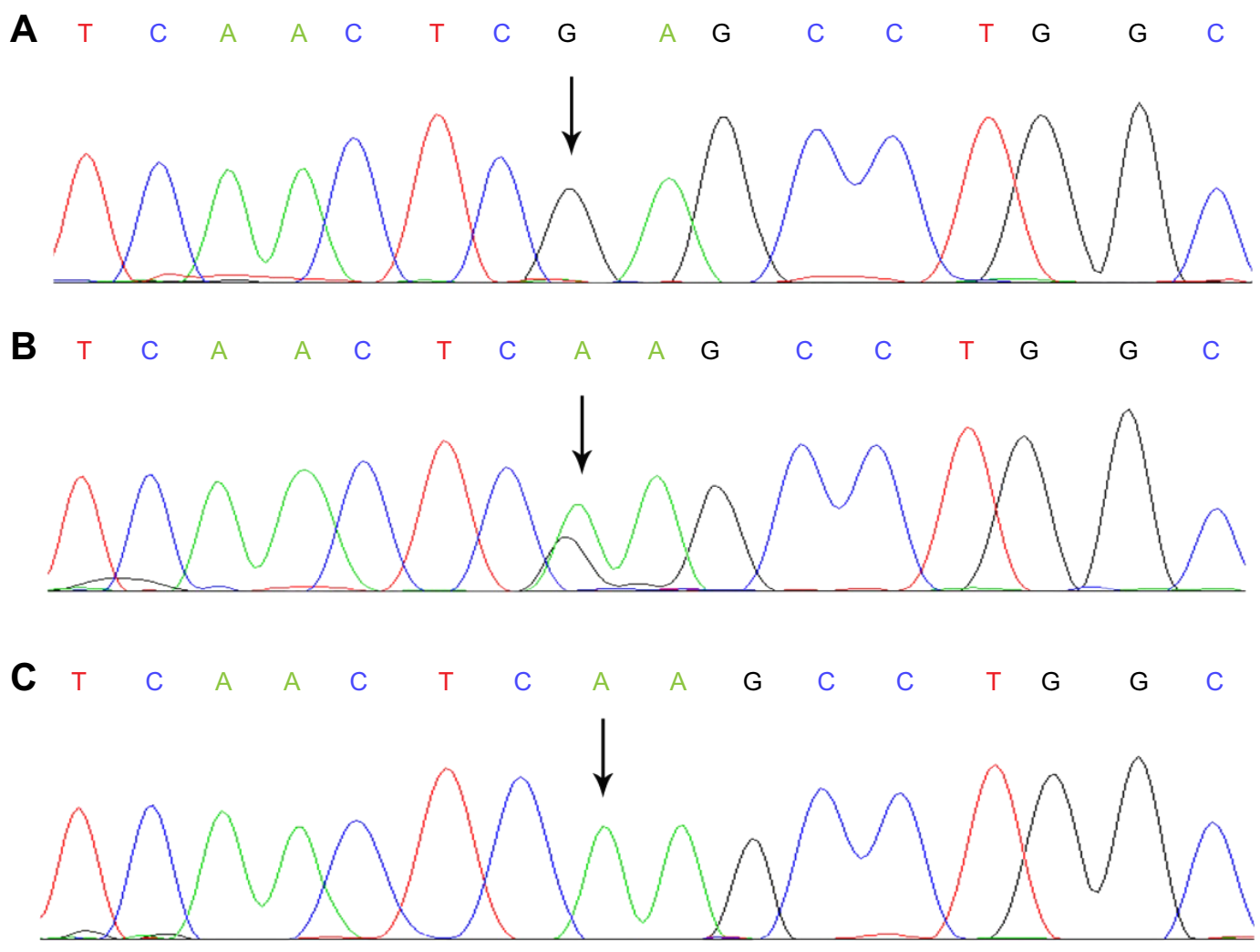

Figure 2 Sequencing map of genotype for IL-27 rs 153109 polymorphism.

Notes: The arrow in (A-C) show GG, AG and AA genotypes, respectively. 
Table 2 IL-27 rsI53I09 polymorphism in CRC patients and healthy controls

\begin{tabular}{|c|c|c|c|c|}
\hline & $\begin{array}{l}\text { CRC patient } \\
\mathrm{N}=600 \text { (\%) }\end{array}$ & $\begin{array}{l}\text { Control } \\
\mathrm{N}=600 \text { (\%) }\end{array}$ & OR $(95 \% \mathrm{Cl})$ & $P$-value \\
\hline \multicolumn{5}{|c|}{ Genotype frequency } \\
\hline GG & $140(23.3)$ & $127(2 \mid .2)$ & $1.382(1.024-1.864)$ & 0.034 \\
\hline GA & $243(40.5)$ & $201(33.5)$ & $1.515(1.170-1.962)$ & 0.002 \\
\hline AA & $217(36.2)$ & $272(45.3)$ & I.00 (reference) & \\
\hline \multicolumn{5}{|c|}{ Allele frequency } \\
\hline Allele G & $523(43.6)$ & 455 (37.9) & 1.265 (I.074-I.489) & 0.001 \\
\hline Allele A & $677(56.4)$ & $745(62.1)$ & I.00 (reference) & \\
\hline \multicolumn{5}{|c|}{ Genotype frequency } \\
\hline GG or GA & $383(63.8)$ & $328(54.7)$ & $1.797(1.344-2.404)$ & 0.001 \\
\hline AA & $217(36.2)$ & $272(45.3)$ & I.00 (reference) & \\
\hline \multicolumn{5}{|c|}{ Genotype frequency } \\
\hline GG & $140(23.3)$ & $127(2 \mid .2)$ & I.I34 (0.863-I.488) & 0.367 \\
\hline $\mathrm{AA}$ or $\mathrm{GA}$ & $460(76.7)$ & $473(78.8)$ & I.00 (reference) & \\
\hline
\end{tabular}

Abbreviations: $\mathrm{CRC}$, colorectal cancer; OR, odds ratio; $\mathrm{Cl}$, confidence interval.

but also has indirect antitumor effects driven by immune stimulatory activity in many cancers. ${ }^{6-11}$ Recently published data confirmed that the IL-27 rs153109 polymorphism was associated with cancer risk, but how this contributes to CRC is unknown. ${ }^{12-16}$ Thus, we investigated this association.

We found that GG, GA, and combined A variant genotypes $(\mathrm{GG}+\mathrm{GA})$ conferred significantly greater risk of $\mathrm{CRC}$ and that $\mathrm{G}$ alleles were associated with higher susceptibility to CRC. Stratified analyses for combined genotypes (GG + GA versus AA) did not reveal differences within a
CRC patient subgroup according to sex, age at admission, differentiation status, tumor growth pattern, lymph node metastasis, and TNM pathological stage. So, we did link the IL-27 rs153109 polymorphism and CRC risk but larger multicenter studies are needed to confirm our data and assess the validity of this single nucleotide polymorphism as a cancer screening marker.

\section{Acknowledgment}

This research was supported by the National Natural Science Foundation of China (grant number 81372380).

Table 3 Association between IL-27 rs I53109 polymorphism and clinicopathological characteristic of CRC patients

\begin{tabular}{|c|c|c|c|c|c|}
\hline \multirow[t]{3}{*}{ Characteristic } & \multirow{3}{*}{$\begin{array}{l}\text { Cases } \\
\mathrm{N}=600 \text { (\%) }\end{array}$} & \multicolumn{2}{|l|}{ Genotype no } & \multirow[t]{3}{*}{ OR (95\% Cl) } & \multirow[t]{3}{*}{$P$-value } \\
\hline & & $\mathbf{N}=\mathbf{3 8 3}$ & $N=217$ & & \\
\hline & & GA + GG (\%) & AA (\%) & & \\
\hline \multicolumn{6}{|l|}{ Age } \\
\hline$<50$ years & $186(31.0)$ & II4 (29.8) & $72(33.2)$ & $0.854(0.597-1.220)$ & 0.385 \\
\hline$\geq 50$ years & $4 \mid 4(69.0)$ & $269(70.2)$ & $145(66.8)$ & 1.00 (reference) & \\
\hline \multicolumn{6}{|l|}{ Sex } \\
\hline Male & $350(58.3)$ & $228(59.5)$ & $122(56.2)$ & I.I45 (0.8I8-1.605) & 0.430 \\
\hline Female & $250(4 I .7)$ & $155(40.5)$ & $95(43.8)$ & I.00 (reference) & \\
\hline \multicolumn{6}{|l|}{ Growth pattern } \\
\hline Ulcerative & $226(37.7)$ & $139(36.3)$ & $87(40.1)$ & $0.85 \mid(0.605-1.199)$ & 0.356 \\
\hline Protruding & $374(62.3)$ & $244(63.7)$ & I 30 (59.9) & 1.00 (reference) & \\
\hline \multicolumn{6}{|l|}{ Differentiation } \\
\hline Good & $274(45.7)$ & $172(44.9)$ & $102(47.0)$ & $0.919(0.658-1.284)$ & 0.620 \\
\hline Poor + moderate & $326(54.3)$ & $211(55.1)$ & $115(53.0)$ & I.00 (reference) & \\
\hline \multicolumn{6}{|c|}{ Lymph node metastasis } \\
\hline Yes & $348(58.0)$ & $226(59.0)$ & $122(56.2)$ & 1.121 (0.800-I.570) & 0.506 \\
\hline No & $252(42.0)$ & $157(40.9)$ & $95(43.8)$ & 1.00 (reference) & \\
\hline \multicolumn{6}{|c|}{ TNM pathological stage } \\
\hline I and II & $228(38.0)$ & $140(36.6)$ & $88(40.6)$ & $0.845(0.600-1.189)$ & 0.332 \\
\hline III and IV & $372(62.0)$ & $243(63.4)$ & $129(59.4)$ & $\mathrm{I} .00$ (reference) & \\
\hline
\end{tabular}

Abbreviations: CRC, colorectal cancer; OR, odds ratio; $\mathrm{Cl}$, confidence interval; TNM, Tumor-Node-Metastasis. 


\section{Disclosure}

The authors report no conflicts of interest in this work.

\section{References}

1. Jemal A, Bray F, Center MM, Ferlay J, Ward E, Forman D. Global cancer statistics. CA Cancer J Clin. 2011;61(2):69-90.

2. Arends MJ. Pathways of colorectal carcinogenesis. Appl Immunohistochem Mol Morphol. 2013;21(2):97-102.

3. Jia WH, Zhang B, Matsuo K, et al. Genome-wide association analyses in East Asians identify new susceptibility loci for colorectal cancer. Nat Genet. 2013;45(2):191-196.

4. Hu Y, Sun Z, Zhang A, Zhang J. SMAD7 rs12953717 polymorphism contributes to increased risk of colorectal cancer. Tumour Biol. 2014;35(1):695-699.

5. Liu L, Zhong R, Wei S, et al. The Leptin Gene Family and Colorectal Cancer:Interaction with Smoking Behavior and Family History of Cancer. PLoS One. 2013;8(4):e60777.

6. Tagawa M. Cytokine therapy for cancer. Curr Pharm Des. 2000;6(6): 681-699.

7. Pflanz S, Timans JC, Cheung J, et al. IL-27, a heterodimeric cytokine composed of $\mathrm{EBI} 3$ and $\mathrm{p} 28$ protein, induces proliferation of naive $\mathrm{CD} 4+$ T cells. Immunity. 2002;16(6):779-790.

8. Nagai H, Oniki S, Fujiwara S, et al. Antitumor activities of interleukin27 on melanoma. Endocr Metab Immune Disord Drug Targets. 2010; 10(1):41-46.

9. Engel MA, Neurath MF. Anticancer Properties of the IL-12 Family-Focus on Colorectal Cancer. Curr Med Chem. 2010;17(29):3303-3308.

10. Hisada M, Kamiya S, Fujita K, et al. Potent Antitumor Activity of Interleukin-27. Cancer Res. 2004;64(3):1152-1156.

11. Morishima N, Owaki T, Asakawa M, Kamiya S, Mizuguchi J, Yoshimoto T. Augmentation of effector CD8+ T cell generation with enhanced granzyme B expression by IL-27. J Immunol. 2005;175(3): 1686-1693.
12. Tao YP, Wang WL, Li SY, et al. Associations between polymorphisms in IL-12A, IL-12B, IL-12R b1, IL-27 gene and serum levels of IL-12p40, IL-27p28 with esophageal cancer. J Cancer Res Clin Oncol. 2012;138(11):1891-1900.

13. Zhang Z, Zhou B, Wu Y, et al. Prognostic value of IL-27 polymorphisms and the susceptibility to epithelial ovarian cancer in a Chinese population. Immunogenetics. 2014;66(2):85-92.

14. Wei YS, Lan Y, Luo B, Lu D, Nong HB. Association of variants in the interleukin-27 and interleukin-12 gene with nasopharyngeal carcinoma. Mol Carcinog. 2009;48(8):751-757.

15. Peng Q, Qin X, He Y, et al. Association of IL27 gene polymorphisms and HBV-related hepatocellular carcinoma risk in a Chinese population. Infect Genet Evol. 2013;16:1-4.

16. Zhao B, Meng LQ, Huang HN, Pan Y, Xu QQ. A novel functional polymorphism, $16974 \mathrm{~A} / \mathrm{C}$, in the interleukin-12-3'untranslated region is associated with risk of glioma. DNA Cell Biol. 2009;28(7):335-341.

17. Chae SC, Li CS, Kim KM, et al. Identification of polymorphisms in human interleukin-27 and their association with asthma in a Korean population. J Hum Genet. 2007;52(4):355-361.

18. Huang N, Liu L, Wang XZ, et al. Association of interleukin (IL)-12 and IL-27 gene polymorphisms with chronic obstructive pulmonary disease in a Chinese population. DNA Cell Biol. 2008;27(9):527-531.

19. Li CS, Zhang Q, Lee KJ, et al. Interleukin-27 polymorphisms are associated with inflammatory bowel diseases in a Korean population. J Gastroenterol Hepatol. 2009;24(10):1692-1696.

20. Zhao P, Dai M, Chen W, Li N. Cancer trends in China. Jpn J Clin Oncol. 2010;40(4):281-285.

21. Risch N, Merikangas K. The future of genetic studies of complex human diseases. Science. 1996;273(5281):1516-1517.
OncoTargets and Therapy

\section{Publish your work in this journal}

OncoTargets and Therapy is an international, peer-reviewed, open access journal focusing on the pathological basis of all cancers, potential targets for therapy and treatment protocols employed to improve the management of cancer patients. The journal also focuses on the impact of management programs and new therapeutic agents and protocols on

\section{Dovepress}

patient perspectives such as quality of life, adherence and satisfaction. The manuscript management system is completely online and includes a very quick and fair peer-review system, which is all easy to use. Visit http://www.dovepress.com/testimonials.php to read real quotes from published authors. 